\title{
Correlation between the Laboratory Test Results and Knee Functional Improvement of Pre- and Post-Total Knee Replacement Operation
}

\author{
Naranbat Lkhagvasuren, Puntsag Chultemsuren, Munkhbaatar Dagvasumberel, Anujin Batbold, \\ Zolbayar Baasanjav, Battulga Khaltar, Otgonsaikhan Nomkhondorj, Batsukh Ombogo, \\ Erdenebileg Avirmed, Avirmed Amgalanbaatar, Munkhbayarlakh Sonomjamts
}

Department of Orthopeadic, School of Medicine, Mongolian National University of Medical Sciences, Ulaanbaatar, Mongolia

Email: naranbat@mnums.edu.mn

How to cite this paper: Lkhagvasuren, N., Chultemsuren, P., Dagvasumberel, M., Batbold, A., Baasanjav, Z., Khaltar, B., Nomkhondorj, O., Ombogo, B., Avirmed, E., Amgalanbaatar, A. and Sonomjamts, M. (2019) Correlation between the Laboratory Test Results and Knee Functional Improvement of Pre- and Post-Total Knee Replacement Operation. Open Journal of Orthopedics, 9, 48-60.

https://doi.org/10.4236/ojo.2019.93005

Received: January 30, 2019

Accepted: March 8, 2019

Published: March 11, 2019

Copyright () 2019 by author(s) and Scientific Research Publishing Inc. This work is licensed under the Creative Commons Attribution International License (CC BY 4.0).

http://creativecommons.org/licenses/by/4.0/

(c) (i) Open Access

\begin{abstract}
Objective: This study aimed to identify correlations of laboratory test results and knee joint function between pre- and post-operation of knee joint replacement surgery. Methods: The study covered 60 - 75 aged 50 patients who had operated with knee replacement surgery. 25 patients were male and another 25 patients were female. We compared laboratory test results of preand $3^{\text {rd }}, 7^{\text {th }}$ and $14^{\text {th }}$ day of post-operation. Moreover, pre-operation knee joint function was compared with $3^{\text {rd }}, 7^{\text {th }}, 14^{\text {th }}$ and $30^{\text {th }}$ day of post-operation. Furthermore, we investigated the relationship among WBC, hemoglobin and function tests. Pre- and post-operative knee joint function tests were conducted by WOMAC (The Western Ontario and McMaster Universities Osteoarthritis), VAS (Visual Analogue Scale), TUG (Time up and Go) score, and MMT (Muscle Manual Test). Results: In pre-operation, patients' average WBC was $6.447 \pm 2.115$ cells $/ \mu \mathrm{L}$, monocyte was $6.554 \pm 3.101$ cells $/ \mu \mathrm{L}$, lymphocyte was $31.177 \pm 9.512$ cells $/ \mu \mathrm{L}$ and C-reactive protein was $0.6205 \pm$ $0.922 \mathrm{mg} / \mathrm{dL}$. In $3^{\text {rd }}$ day of post-operation, WBC was $8.901 \pm 2.869$ cells $/ \mu \mathrm{L}$, monocyte was $4.881 \pm 2.332$ cells $/ \mu \mathrm{L}$, lymphocyte was $17.048 \pm 9.702$ cells $/ \mu \mathrm{L}$ and C-reactive protein was $4.2762 \pm 2.293 \mathrm{mg} / \mathrm{dL}$. There was a statistically significant difference reported on pre- and post- operation pain, stiffness and daily activity $(\mathrm{P}<0.001)$. On the other hand, patients' post-operative TUG score was significantly higher than pre-operative TUG scores $(P<0.0001)$. Furthermore, hemoglobin, red blood cell and TUG score of the $3^{\text {rd }}$ day of post-operation were raised up and they were statistically significant $(\mathrm{P}<0.036)$.
\end{abstract}


In addition, WBC of pre-operation and $3^{\text {rd }}, 7^{\text {th }}, 14^{\text {th }}$ day of TUG score was significantly correlated $(\mathrm{P}<0.04)$. Conclusion: Results of WBC, hemoglobin, hematocrit, total protein, total bilirubin, and creatinine had increased in $3^{\text {rd }}$ and $7^{\text {th }}$ day of post-operation and had stabilized from $14^{\text {th }}$ day of post-operation. Stiffness and TUG performance were controversially correlated in $3^{\text {rd }}, 7^{\text {th }}$, $14^{\text {th }}, 30^{\text {th }}$ day of post-operation. However, in $7^{\text {th }}$ and $14^{\text {th }}$ of post-operation, patients' muscle strength and knee joint amplitude had become stabilized and improved from $30^{\text {th }}$ day of post-operation. Moreover, after the operation, the number of WBC controversially affected patients' mobility. In addition, we found that as hemoglobin and red blood cells increased, walking ability improved as well.

\section{Keywords}

TUG, WOMAC, VAS, WHO

\section{Introduction}

According to the World Health Organization (WHO) study in 1998-2015, the prevalence of Osteoarthritis (OA) is increasing $10 \%-15 \%$ year by year [1]. Moreover, the burden of musculoskeletal disability is increasing due to OA. In Mongolia, an incidence of OA and OA related surgery has been rising as well [1].

Knee joint replacement surgery is one of the effective treatments. Moreover, studying laboratory test before and after the surgery is important. In addition, there is no study having reported in Mongolia about laboratory test of knee replacement surgery [2].

Curtis et al. studied inflammatory factors after knee replacement surgery. The study reported that enhanced C-reactive protein, WBC and neutrophil percentage considered potential indicators to diagnose periprosthetic joint infection. It was usually developed by Staphylococcus epidermis and it was diagnosed by 5 - 6 pieces' tissue of biopsy [3].

They studied about 2 stages of antibiotic treatment for 4 weeks before surgical treatment of prosthesis for infection detected patients [4].

Alijanipour and Parvizi studied inflammatory markers for diagnosing periprosthetic joint infection (PJI). Inflammatory markers included $1 \beta$, IL-4, IL-6, IL-17A, TNF (ELISA), CRP, ESR and WBC and were considered important factors [5].

American Academy of Orthopaedic Surgeon (AAOS) classified the periprosthetic joint infection into 3 classifications.

1) Acute (less than 3 months);

2) Moderate (3 - 24 months);

3) Chronic (more than 24 months).

As AAOS defined, optimal threshold for CRP and ESR was $149 \mathrm{~mm} /$ hour and $14.5 \mathrm{mg} / \mathrm{dL}$ in PJI knee [6]. 
The average monthly cost for PJI knee was $\$ 50.000$ while the average cost of a year was 250 million dollars among United States patients [7].

In 1974, the first patellar replacement was introduced as well as joint surface replacing. After that, scientists developed the method of installing prosthesis with bone-cement and retaining anterior and posterior cruciate ligaments [8].

In modern days, there are more than 19 companies producing 3 types of joint prosthesis. Internationally, many scientists have been studying laboratory test results of pre- and post-operation of total knee joint replacement [9].

Knee joint replacement surgery was introduced in Mongolia in 2000 with the help of orthopedic surgeons from France. Nowadays, the prevalence of osteoarthritis has been increasing in Mongolia

Therefore, total knee joint arthroplasty is one of the notable treatments. Moreover, the study of serologic markers before and after joint prosthesis surgery has never been done in Mongolia.

\section{Materials and Methods}

We've covered 60 - 75 aged 50 patients who had operated with knee joint replacement surgery in National Trauma and Injury Hospital between June, 2017 and December 2018. 25 patients were male and another 25 patients were female.

We compared patients' pre- and $3^{\text {rd }}, 7^{\text {th }}, 14^{\text {th }}$ day of post-operation laboratory test results and also pre- and $3^{\text {rd }}, 7^{\text {th }}, 14^{\text {th }}$ and $30^{\text {th }}$ day of post-operation knee joint function. Furthermore, red blood cell and hemoglobin indications were compared with walking test results.

The study all laboratory tests conducted in National Trauma and Injury Hospital.

Patients' knee joint function including pain, stiffness and daily activity were examined by WOMAC. Pain intensity was evaluated by VAS score. Walking test was assessed by TUG score. Moreover, MMT test assessed the muscle strength [10] [11] [12].

Exclusion criteria were foreign person, who has psychological disorder, bone cancer, osteomyelitis, thrombosis, lower extremities paralysis, cardiovascular diseases and diabetes mellitus type 2 .

\section{Statistical Analysis}

All statistical analysis made with Stata 13.0 IC program. We've summarized calculation of median and standard deviation of more than 2 times of (4 - 5 times) laboratory tests measurements with a normal distribution. F value of Greenhouse Geisser test was used to find the correlation between groups. $\mathrm{P}$ value is less than 0.05 is considered as statistically significant. When it has a non-normal distribution, non-parametric Friedman test was used. Those repeated test results were represented by GraphPad Prism 7.0.

\section{Ethical Statement}

Ethical approval for this study was acquired from the Research Ethics Commit- 
tee of the Mongolian National University of Medical Sciences on $18^{\text {th }}$ May, 2018 with \#3-09 order. Before data collection, the participants signed a written, informed consent

\section{Result}

In this study, we've covered 50 patients who have had total knee arthroplasty. Patients' average age was $66.5 \pm 9$ and the gender ratio was $1: 1$.

\subsection{Complete Blood Count Test}

Patients' average WBC of pre-operation was $6.447 \pm 2.115$ cells/ $\mu \mathrm{L}$, monocyte was $6.554 \pm 3.101$ cells $/ \mu \mathrm{L}$, lymphocyte was $31.177 \pm 9.512$ cells $/ \mu \mathrm{L}$ and C-reactive protein was $0.6205 \pm 0.922 \mathrm{mg} / \mathrm{dL}$.

$3^{\text {rd }}$ day of post-operation, WBC was $8.901 \pm 2.869$ cells $/ \mu \mathrm{L}$, monocyte was $4.881 \pm 2.332$ cells $/ \mu \mathrm{L}$, lymphocyte was $17.048 \pm 9.702$ cells/ $\mu \mathrm{L}$ and C-reactive protein was $4.2762 \pm 2.293 \mathrm{mg} / \mathrm{dL}$. $7^{\text {th }}$ day of post-operation, WBC was $8.186 \pm$ 3.125 cells $/ \mu \mathrm{L}$, monocyte was $6.266 \pm 2.913$ cells $/ \mu \mathrm{L}$, lymphocyte was $21.907 \pm$ 7.955 cells $/ \mu \mathrm{L}, \mathrm{C}$-reactive was $2.8954 \pm 2.964 \mathrm{mg} / \mathrm{d}$. $14^{\text {th }}$ day of post-operation, WBC was $7.308 \pm 2.385$ cells $/ \mu \mathrm{L}$, monocyte was $6.918 \pm 3.528$ cells $/ \mu \mathrm{L}$, lymphocyte was $23.278 \pm 8.966$ cells $/ \mu \mathrm{L}, \mathrm{C}$-reactive protein was $1.6676 \pm 1.367 \mathrm{mg} / \mathrm{dL}$ (Table 1).

Patients' WBC correlation between pre- and post-operation was identified by F value of Greenhouse Geisser test. As a test result, it was correlated statistically significant $(\mathrm{P}<0.0001)$ (Figure 1$)$.

However, there was no significant correlation of monocyte test result between pre- and post-operation $(\mathrm{P}>0.405)$ (Figure 2). Even though, there was a significant correlation was observed lymphocyte result between pre- and postoperation $(\mathrm{P}<0.05)$ (Figure 3$)$.

Moreover, there was no significant correlation observed on CRP ( $\mathrm{P}>0.21$ ). Furthermore, there was no statistically significant difference in laboratory test result between male and female patients $(\mathrm{P}>0.09)$ (Figure 4).

Table 1. Laboratory test results of pre and post operation.

\begin{tabular}{|c|c|c|c|c|c|c|c|}
\hline & \multirow{2}{*}{$\begin{array}{l}\text { Pre-operation } \\
\qquad \mathrm{M} \pm \mathrm{SD}\end{array}$} & \multicolumn{3}{|c|}{ Post-operation [M $\pm \mathrm{SD}]$} & \multicolumn{2}{|c|}{$95 \% \mathrm{CI}$} & \multirow{2}{*}{ P-value } \\
\hline & & $3^{\text {rd day }}$ & $7^{\text {th }}$ day & $14^{\text {th }}$ day & $\min$ & $\max$ & \\
\hline Monocyte & $6.554 \pm 3.101$ & $4.881 \pm 2.332$ & $6.266 \pm 2.913$ & $6.918 \pm 3.528$ & 2.00 & 21.10 & $0.71^{\ddagger}$ \\
\hline Lymphocyte & $31.177 \pm 9.512$ & $17.048 \pm 9.702$ & $21.907 \pm 7.955$ & $23.278 \pm 8.966$ & 8.10 & 46.20 & $0.05^{\ddagger}$ \\
\hline C-reactive protein & $0.6205 \pm 0.922$ & $4.2762 \pm 2.293$ & $2.8954 \pm 2.964$ & $1.6676 \pm 1.367$ & 0.02 & 5.12 & $0.241^{\ddagger}$ \\
\hline Hemoglobin & $134.51 \pm 16.97$ & $117.49 \pm 15.06$ & $111.48 \pm 18.03$ & $111.90 \pm 15.58$ & 98 & 141 & $0.0001^{\dagger}$ \\
\hline Hematocrit & $38.64 \pm 5.51$ & $32.29 \pm 6.04$ & $30.71 \pm 5.77$ & $30.89 \pm 4.82$ & 20 & 39 & $0.0001^{\dagger}$ \\
\hline Platelet & $273.68 \pm 102.4$ & $221.02 \pm 71.46$ & $265.7 \pm 79.7$ & $306.1 \pm 111.1$ & 120 & 340 & $0.047^{\ddagger}$ \\
\hline
\end{tabular}

Unit $(+3 \mathrm{Em} / \mathrm{ml}, \mathrm{mg} / \mathrm{dL}) ;{ }^{\dagger}$ Green House Geisser F-value used when it has normal distribution; ${ }^{\ddagger}$ Freidman test used for non-normal distribution. 


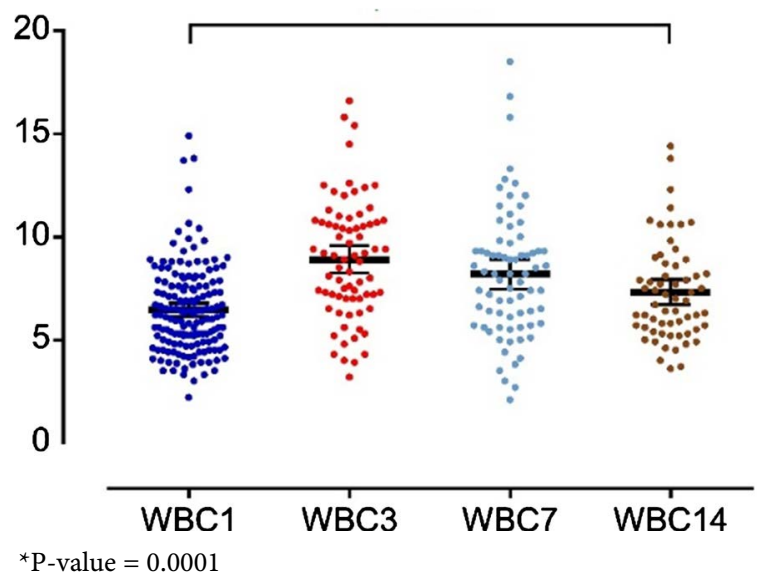

Figure 1. WBC number of pre- and post-operation.

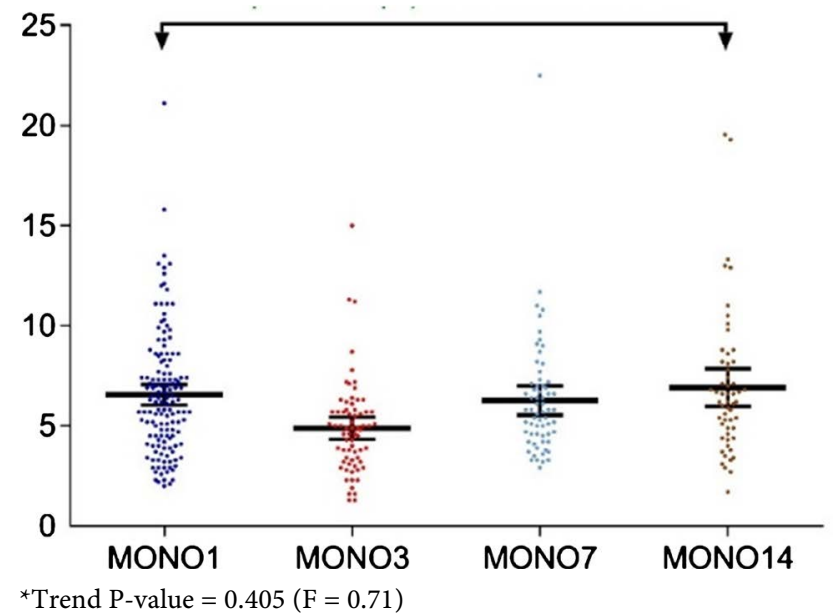

Figure 2. Monocyte number of pre- and post-operation.

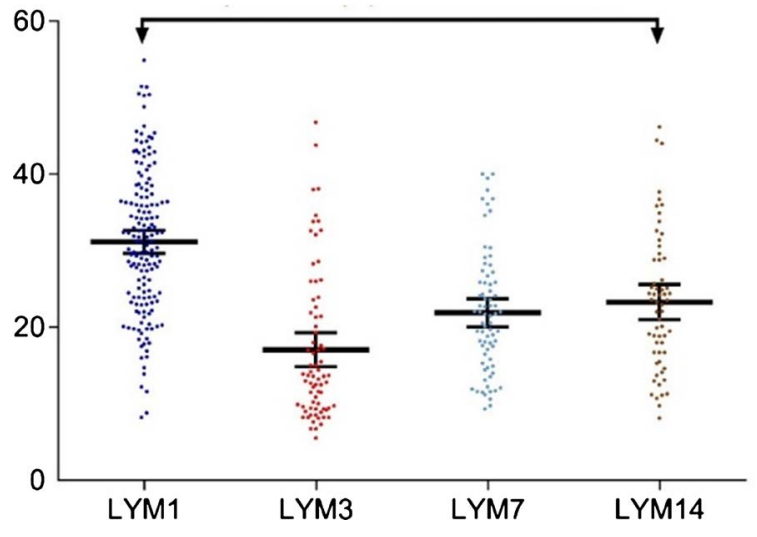

${ }^{\star}$ Trend $\mathrm{P}$-value $=0.828(\mathrm{~F}=0.05)$

Figure 3. Lymphocyte number of pre- and post-operation.

When we identified the difference between pre- and post-operation red blood cell and hemoglobin, there was statistically, significant difference reported $(\mathrm{P}<$ 0.001) (Figure 5).

On the other hand, pre-operation hematocrit result was statistically dropped 
in post-operation $(\mathrm{P}<0.001)$ (Figure 6$)$. The number of platelet cells was statistically dropped after the operation as well $(\mathrm{P}<0.047)$ (Figure 7).

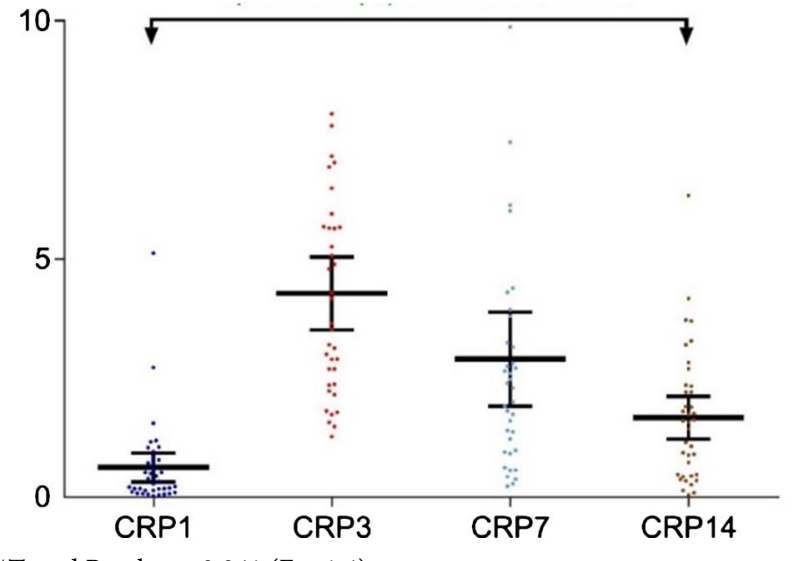

${ }^{*}$ Trend P-value $=0.241(\mathrm{~F}=1.4)$

Figure 4. C-reactive protein number of pre- and post-operation.

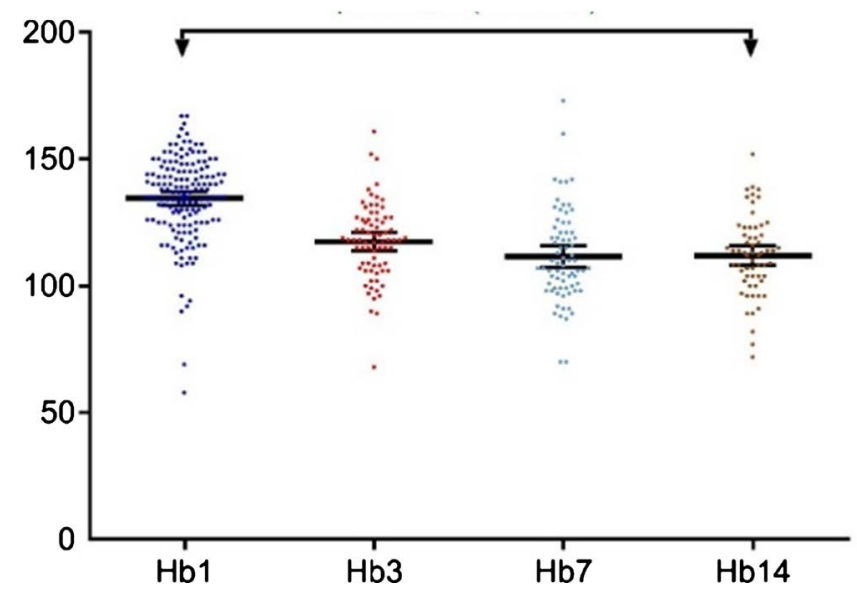

${ }^{*}$ Trend $\mathrm{P}$-value $=0.0001(\mathrm{~F}=57.9)$

Figure 5. Hemoglobin number of pre- and post-operation.

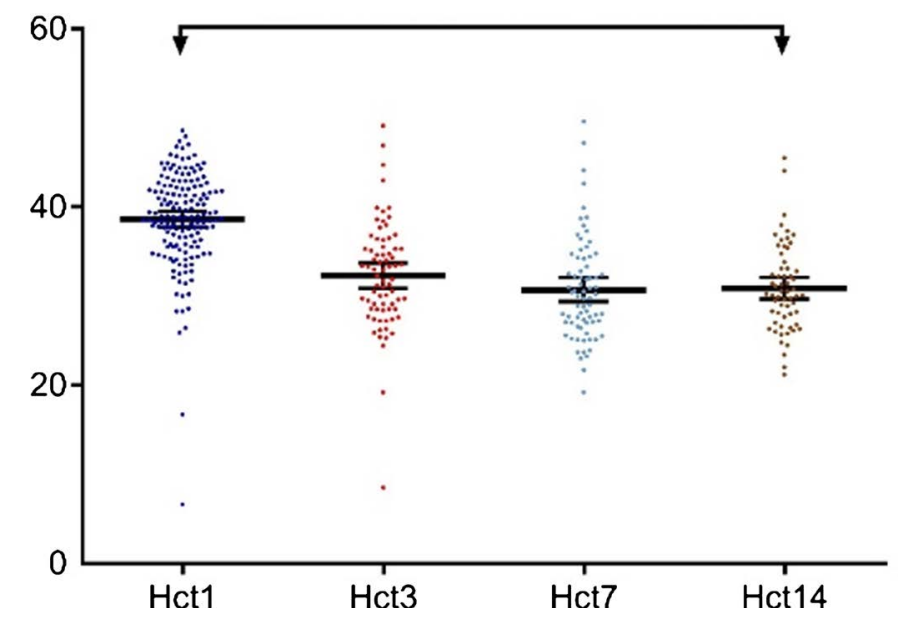

${ }^{\star}$ Trend P-value $=0.0001(\mathrm{~F}=49.4)$

Figure 6. Hematocrit number of pre- and post-operation. 


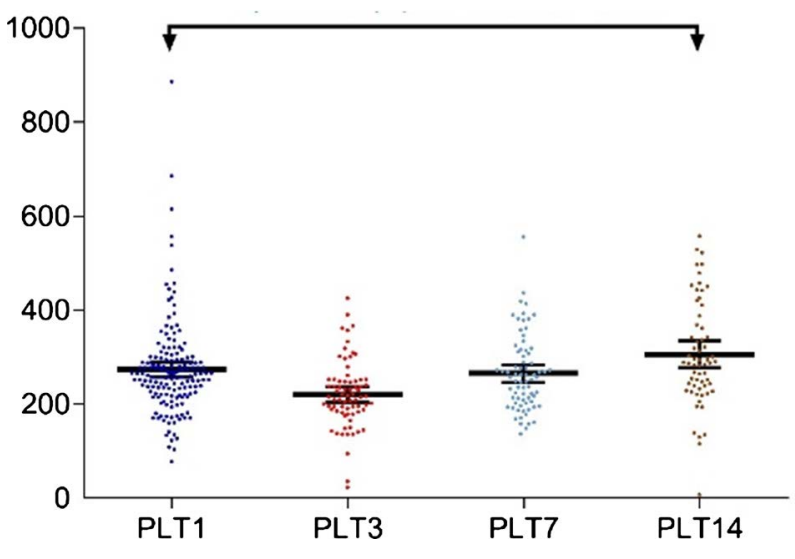

*Trend P-value $=0.047(\mathrm{~F}=4.23)$

Figure 7. Platelet number of pre- and post-operation.

\subsection{Result of Biochemical Analysis}

The patients' average ASAT result of pre-operation was $25.7 \pm 15.9 \mathrm{U} / \mathrm{L}$, average ALAT result was $29.8 \pm 22.6 \mathrm{U} / \mathrm{L}$, average total protein was $7.72 \pm 4.78 \mathrm{~g} / \mathrm{dL}$, average total bilirubin was $0.61 \pm 0.29 \mathrm{mg} / \mathrm{dL}$ and average creatinine was $0.69 \pm$ $0.28 \mathrm{mg} / \mathrm{dL}$.

In $3^{\text {rd }}$ day of post-operation, average ASAT result was $26.5 \pm 13.6 \mathrm{U} / \mathrm{L}$, average ALAT result was $27.6 \pm 16.4 \mathrm{U} / \mathrm{L}$, average total protein was $7.56 \pm 9.24 \mathrm{~g} / \mathrm{dL}$, average total bilirubin was $0.86 \pm 0.37 \mathrm{mg} / \mathrm{dL}$ and average creatinine was $0.66 \pm$ $0.23 \mathrm{mg} / \mathrm{dL}$.

In $7^{\text {th }}$ day of post-operation, average ASAT result was $33.3 \pm 29.7 \mathrm{U} / \mathrm{L}$, average ALAT result was $33.2 \pm 23.8 \mathrm{U} / \mathrm{L}$, average total protein was $6.57 \pm 0.67 \mathrm{~g} / \mathrm{dL}$, average total bilirubin was $0.91 \pm 0.81 / \mathrm{dL}$ and average creatinine was $0.61 \pm 0.21$ $\mathrm{mg} / \mathrm{dL}$.

In $14^{\text {th }}$ day of post-operation, average ASAT result was $33.6 \pm 33.2 \mathrm{U} / \mathrm{L}$, average ALAT result was $49.3 \pm 67.2 \mathrm{U} / \mathrm{L}$, average total protein was $6.52 \pm 0.75 \mathrm{~g} / \mathrm{dL}$, average total bilirubin was $0.79 \pm 0.37 / \mathrm{dL}$ and average creatinine was $0.58 \pm 0.16$ $\mathrm{mg} / \mathrm{dL}$ (Table 2).

There was a statistically significant difference reported on result of ASAT of pre and post-operation. It was analyzed by Greenhouse Geisser test $(\mathrm{P}>0.061)$ (Figure 8). However, there was statistically significant difference reported on result of ALAT of pre and post-operation $(\mathrm{P}<0.042)$ (Figure 9). Total protein was statistically decreased after operation $(\mathrm{P}<0.001)$ (Figure 10). Total bilirubin was statistically dropped as well $(\mathrm{P}<0.042)$ (Figure 11$)$.

Also, result of creatinine was statistically different in pre and post-operation $(\mathrm{P}<0.001)$ (Figure 12).

\subsection{Result of Knee Function Tests}

There were statistically significant improvements reported on pre and post-operation WOMAC test including pain, stiffness and daily activity $(\mathrm{P}<0.001)$ (Figure 13). 
Furthermore, walking test result were significantly improved after surgery ( $\mathrm{P}$ $<0.0001$ ) (Figure 14).

Pain intensity was assessed by VAS score and patients' pain intensity were significantly dropped after surgery $(\mathrm{P}<0.0001)$ (Figure 15$)$.

Muscle strength of post-operation was statistically improved as well $(\mathrm{P}<$ 0.0001) (Figure 16).

Table 2. Biochemical analysis result of pre- and post-operation.

\begin{tabular}{|c|c|c|c|c|c|c|c|}
\hline & \multirow{2}{*}{$\begin{array}{l}\text { Pre-operation } \\
\qquad \mathrm{M} \pm \mathrm{SD}\end{array}$} & \multicolumn{3}{|c|}{ Post-operation $[\mathrm{M} \pm \mathrm{SD}]$} & \multicolumn{2}{|c|}{$95 \% \mathrm{CI}$} & \multirow{2}{*}{$P$ value } \\
\hline & & $3^{\text {rd }}$ day & $7^{\text {th }}$ day & $14^{\text {th }}$ day & Min & $\max$ & \\
\hline ALAT & $29.8 \pm 22.6$ & $27.6 \pm 16.4$ & $33.2 \pm 23.8$ & $49.3 \pm 67.2$ & 8.4 & 427.30 & $0.042^{\dagger}$ \\
\hline Total protein & $7.72 \pm 4.78$ & $7.56 \pm 9.24$ & $6.57 \pm 0.67$ & $6.52 \pm 0.75$ & 4.72 & 7.94 & $0.0001^{*}$ \\
\hline Total bilirubin & $0.61 \pm 0.29$ & $0.86 \pm 0.37$ & $0.91 \pm 0.81$ & $0.79 \pm 0.37$ & 0.28 & 2.06 & $0.042^{\ddagger}$ \\
\hline Creatinine & $0.69 \pm 0.28$ & $0.66 \pm 0.23$ & $0.61 \pm 0.21$ & $0.58 \pm 0.16$ & 0.37 & 1.1 & $0.0001^{\ddagger}$ \\
\hline
\end{tabular}

Unit $(+3 \mathrm{Em} / \mathrm{ml}, \mathrm{mg} / \mathrm{dL}) ;{ }^{\dagger}$ Green House Geisser F-value used when it has normal distribution; ${ }^{*}$ Freidman test used for non-normal distribution.

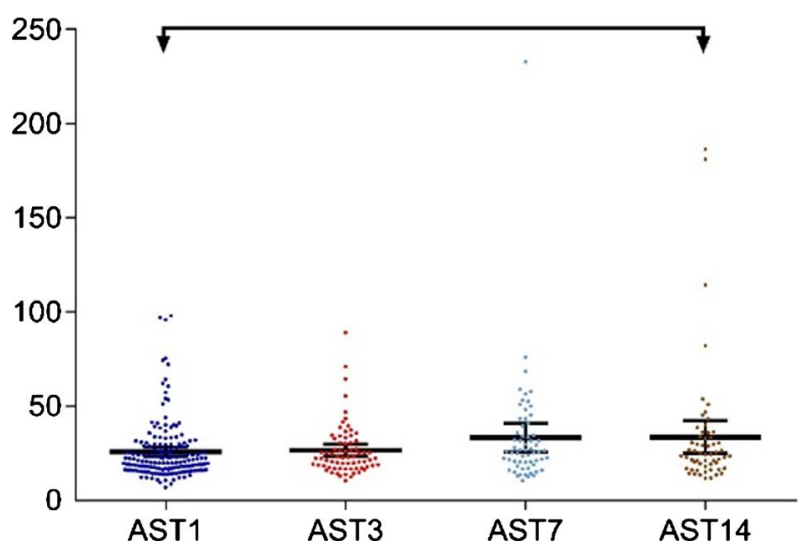

${ }^{*}$ Trend $\mathrm{P}$-value $=0.061(\mathrm{~F}=3.7)$

Figure 8. Result of ASAT of pre- and post-operation.

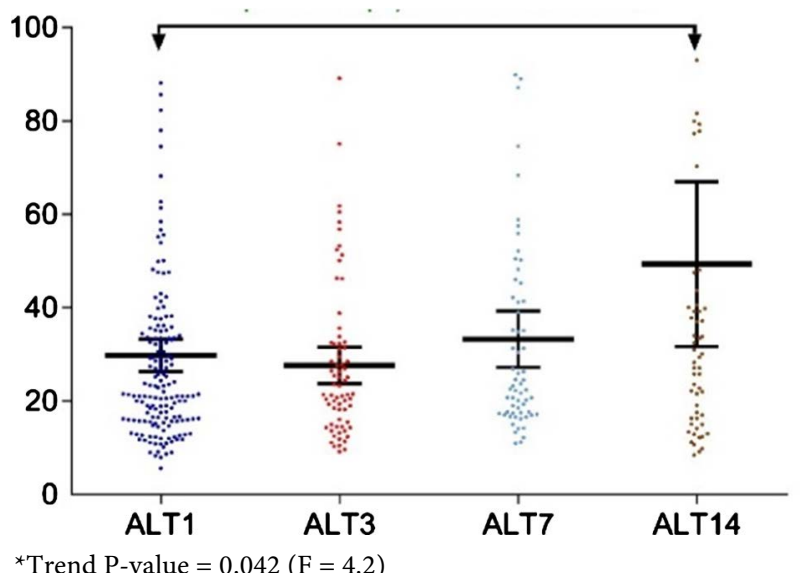

Figure 9. Result of ALAT pre- and post-operation. 


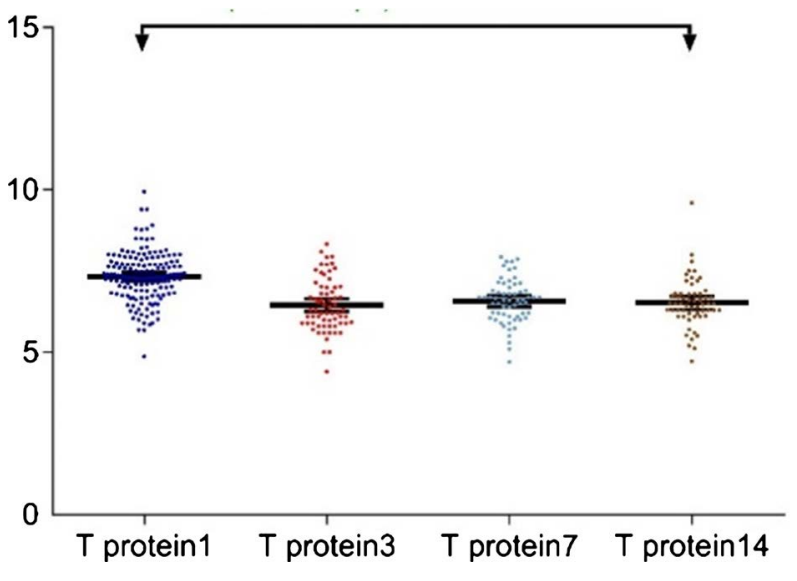

${ }^{*}$ Trend $\mathrm{P}$-value $=0.001(\mathrm{~F}=12.7)$

Figure 10. Result of Total protein pre- and post-operation.

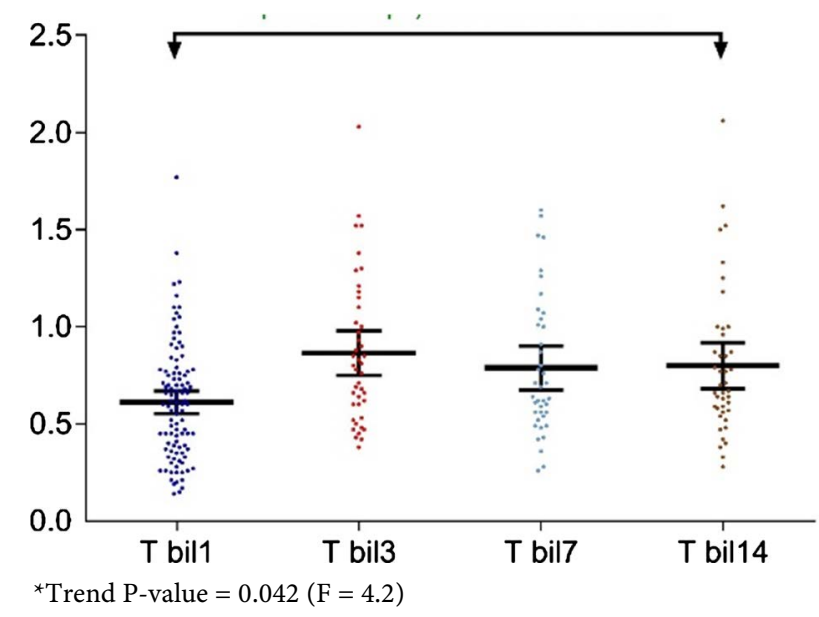

Figure 11. Result of total bilirubin pre- and post-operation.

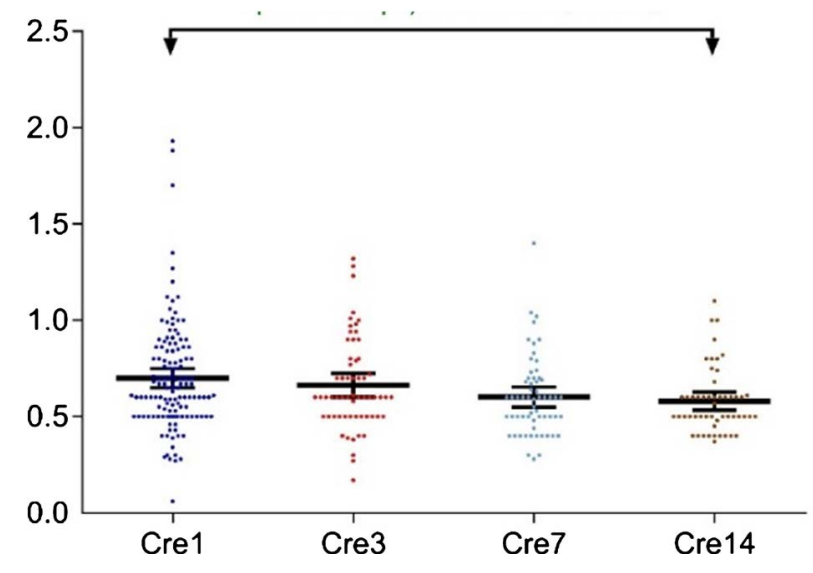

${ }^{\star}$ Trend $\mathrm{P}$-value $=0.042(\mathrm{~F}=4.2)$

Figure 12. Result of creatinine pre- and post-operation.

Post-operation of knee joint arthroplasty, patients' extension, and flexion ability were significantly improved $(\mathrm{P}<0.0001)$ (Figure 17).

There was a statistically significant correlation between result of hemoglobin, 
red blood cell and walking test in a $3^{\text {rd }}$ day of post-operation $(\mathrm{P}<0.036)$ (Figure $18)$.

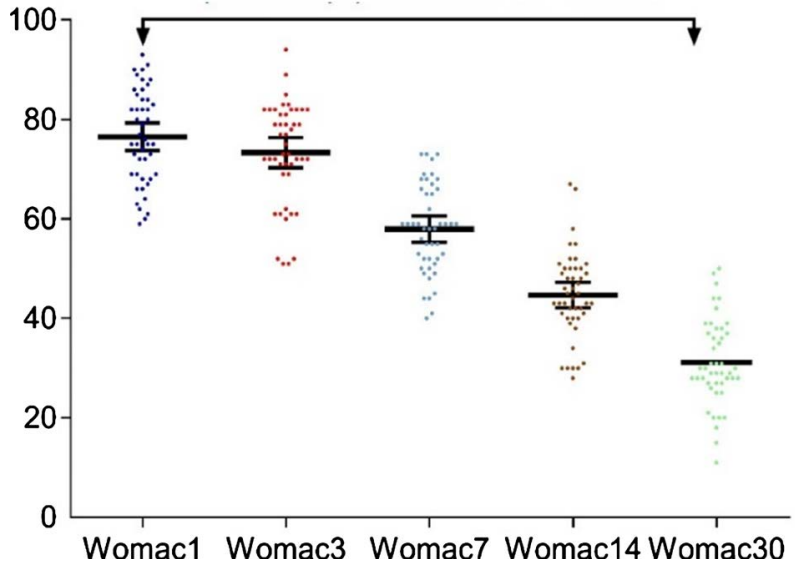

*Trend P-value $=0.0001(\mathrm{~F}=847.4)$

Figure 13. WOMAC test result of pre- and post-operation.

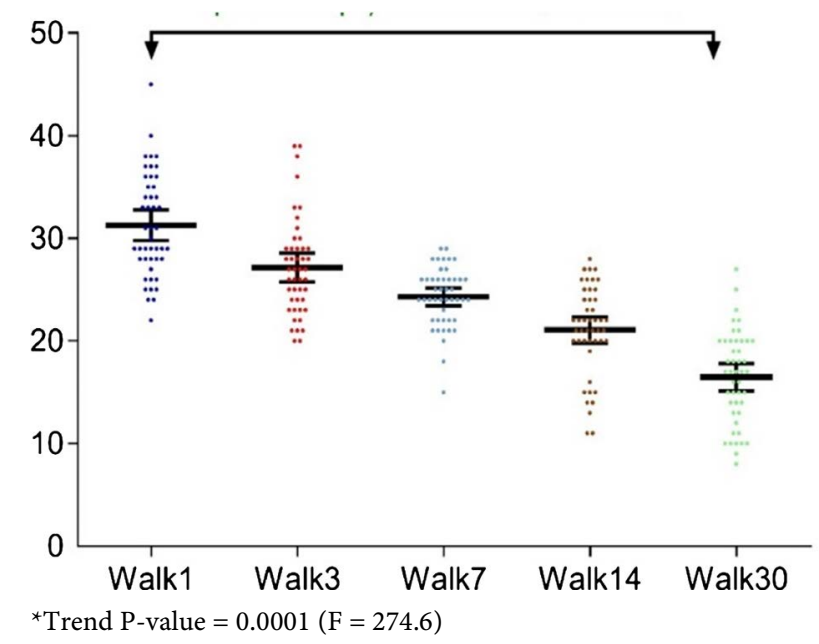

Figure 14. Walking test result of pre- and post-operation.

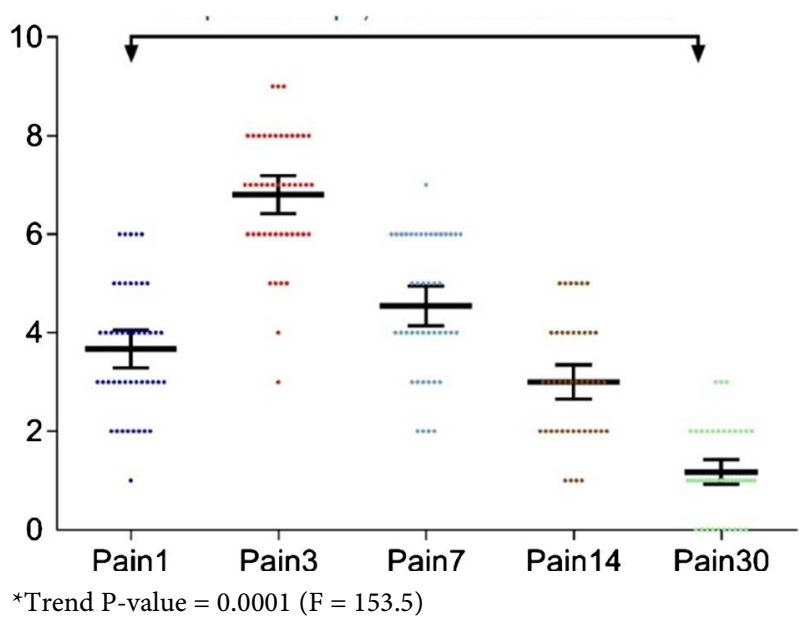

Figure 15. Pain intensity of pre- and post-operation. 


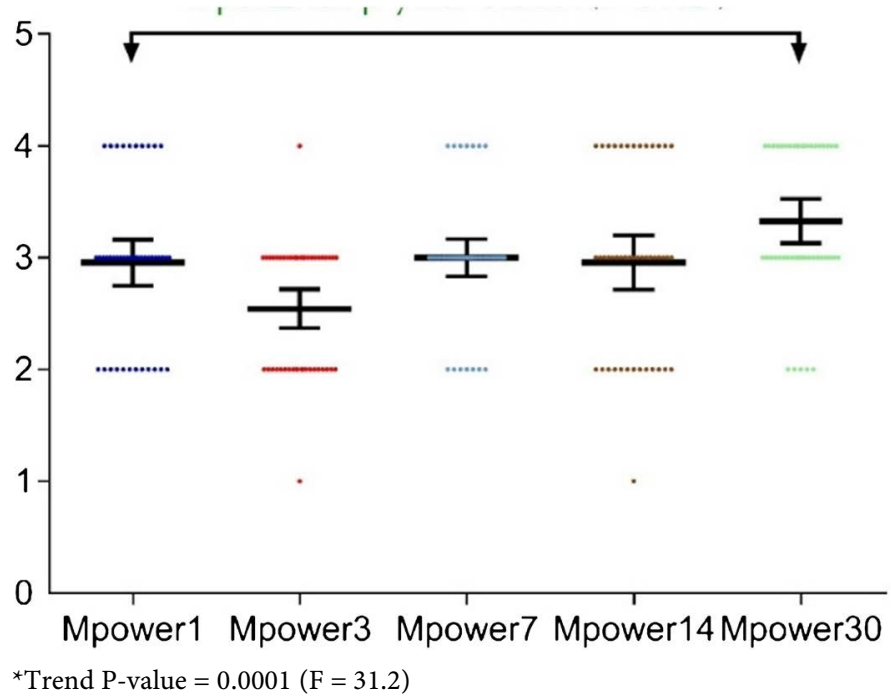

Figure 16. Muscle strength of pre- and post-operation.

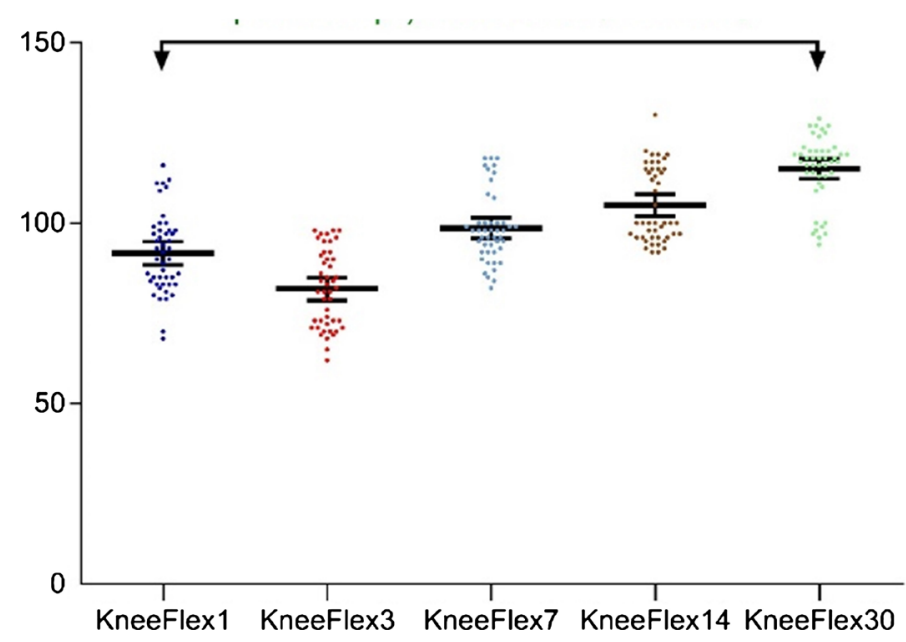

*Trend P-value $=0.0001(\mathrm{~F}=414.4)$

Figure 17. Knee flexion test of pre- and post-operation.

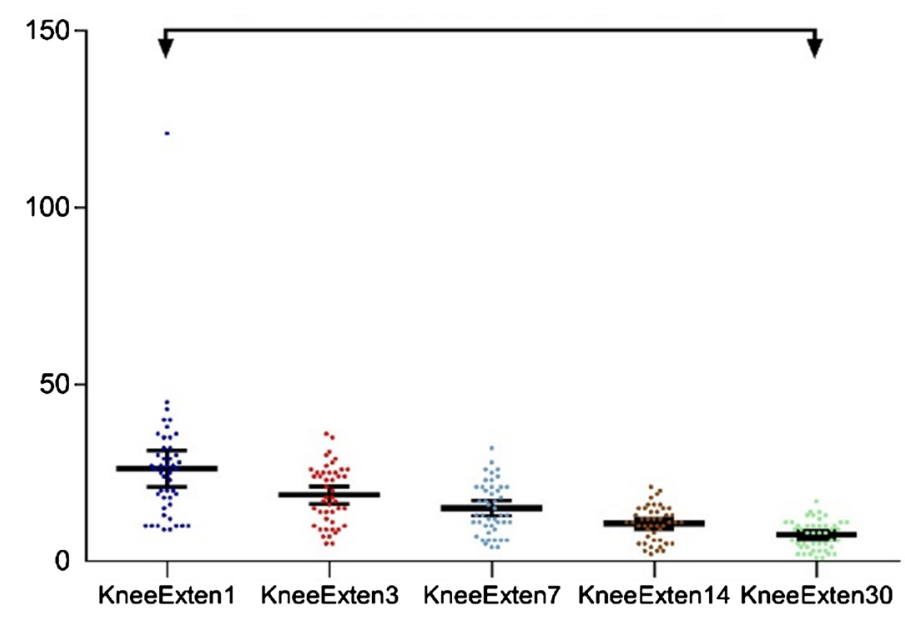

${ }^{*}$ Trend $\mathrm{P}$-value $=0.0001(\mathrm{~F}=75.8)$

Figure 18. Knee extension test of pre- and post-operation. 


\section{Discussion}

Kim et al. have reviewed 28 patients who had infection after total knee arthroplasty between 2003 to 2012 . As a result of this study, $60.7 \%$ of the patients were successfully treated with irrigation and debridement with component retention. Moreover, preoperative ESR, microorganism, and polyethylene liner exchange were factors need to be considered [13].

Leylabadlo et al. have done study in Brazil. As a result of this study, $0.4 \%$ $0.2 \%$ of the total knee arthroplasty had early an infection were and $3.2 \%-5.6 \%$ of them had postoperative late inflammation. Mortality of periprosthetic joint infection after total knee arthroplasty was $0.4 \%-1.2 \%$ among more than 65 years old of people [14].

Everhart et al. reported that $0.51 \%$ postoperative infection recorded from total 8494 cases of periprosthetic joint infection. The people who have obesity, diabetes, young age and higher than $40 \mathrm{BMI}$ are affected by periprosthetic joint infection 3.3 times higher than others [15].

Leighton et al. studied preoperative WBC value of 16,989 patients who underwent total knee arthroplasty and average WBC value before surgery was $7.38 \times 10^{6}$ cells $/ \mu \mathrm{L}$. In our study result, patients' average $\mathrm{WBC}$ was $6.447 \times 10^{6}$ and a statistically significant $(\mathrm{P}<0.0001)$ [11].

Furthermore, $2^{\text {nd }}$ day of post-operation, average $\mathrm{WBC}$ value was $10.5 \times 10^{6}$ cells $/ \mu \mathrm{L}$. However, in our study average WBC was $8.18 \times 10^{6}$ cells $/ \mu \mathrm{L}$ and it has statistically significant difference $(\mathrm{P}<0.0001)$.

In additionally, $14^{\text {th }}$ of post-operation, $\mathrm{WBC}$ was $8.03 \times 10^{6} \mathrm{cells} / \mu \mathrm{L}$. In our study result of WBC was $7.30 \times 10^{6}$ cells $/ \mu \mathrm{L}$ which means both studies recorded a drop of WBC result and it was statistically significant $(\mathrm{P}<0.02)$.

\section{Conclusions}

In conclusion, pre- and post-operation laboratory test of total knee arthroplasty has changed following rehabilitation treatment. Therefore, an early exercise of post-operation is important.

Our study limitation is that patient follow-up time is short and can affect the absolute result of this study. However, we'll continue our study with longer follow-up time in the future. Moreover, we'll investigate prosthesis size for Mongolian people.

\section{Acknowledgements}

We'd like to express our appreciation to National Hospital of Trauma and Injury and Department of Trauma and Injury.

\section{Conflicts of Interest}

The authors have no conflict of interest.

\section{References}

[1] Nik Shafii, N.A.H., Yaacob, L.H., Ishak, A. and Kadir, A.A. (2018) Traditional and 
Complementary Medicine Use in Knee Osteoarthritis and Its Associated Factors among Patients in Northeast Peninsular Malaysia. Oman Medical Journal, 33, 148. https://doi.org/10.5001/omj.2018.27

[2] Carter, E.M. and Potts, H.W. (2014) Predicting Length of Stay from an Electronic Patient Record System: A Primary Total Knee Replacement Example. BMC Medical Informatics and Decision Making, 14, 26. https://doi.org/10.1186/1472-6947-14-26

[3] Curtis, J.R., et al. (2016) Randomized Trial of Communication Facilitators to Reduce Family Distress and Intensity of End-of-Life Care. American Journal of Respiratory and Critical Care Medicine, 193, 154-162. https://doi.org/10.1164/rccm.201505-0900OC

[4] Del Pozo, J.L. and Patel, R. (2009) Infection Associated with Prosthetic Joints. The New England Journal of Medicine, 361, 787-794.

https://doi.org/10.1056/NEJMcp0905029

[5] Alijanipour, P. and Parvizi, J. (2014) Infection Post-Total Knee Replacement: Current Concepts. Current Reviews in Musculoskeletal Medicine, 7, 96-102. https://doi.org/10.1007/s12178-014-9217-z

[6] Radulovic, T.N., et al. (2016) The Effects of Continued Rehabilitation after Primary Knee Replacement. Medical Archives, 70, 131. https://doi.org/10.5455/medarh.2016.131-134

[7] Daines, B.K., Dennis, D.A. and Amann, S. (2015) Infection Prevention in Total Knee Arthroplasty. Journal of the American Academy of Orthopaedic Surgeons, 23, 356-364. https://doi.org/10.5435/JAAOS-D-12-00170

[8] Rosas, S., et al. (2018) Previous History of Breast Cancer Increases Rates of Pulmonary Embolism and Costs after Total Knee Arthroplasty: An Evaluation of 185,114 Matched Patients. The Journal of Knee Surgery.

[9] Paxton, E.W., et al. (2016) Total Joint Replacement: A Multiple Risk Factor Analysis of Physical Activity Level 1 - 2 Years Postoperatively. Acta Orthopaedica, 87, 44-49.

[10] Wink, A.E., et al. (2018) Association of Varus Knee Thrust during Walking with Worsening WOMAC Knee Pain: The Multicenter Osteoarthritis Study. Arthritis Care \& Research. https://doi.org/10.1002/acr.23766

[11] Leighton, R., et al. (2018) Systematic Clinical Evidence Review of NASHA (Durolane Hyaluronic Acid) for the Treatment of Knee Osteoarthritis. Open Access Rheumatology: Research and Reviews, 10, 43.

[12] Anderson, M.L., et al. (2018) Fall Risk and Utilization of Balance Training for Adults with Symptomatic Knee Osteoarthritis: Secondary Analysis from a Randomized Clinical Trial. Journal of Geriatric Physical Therapy. https://doi.org/10.1519/JPT.0000000000000213

[13] Kim, J.G., Bae, J.H., Lee, S.Y., Cho, W.T. and Lim, H.C. (2015) The Parameters Affecting the Success of Irrigation and Debridement with Component Retention in the Treatment of Acutely Infected Total Knee Arthroplasty. Clinics in Orthopedic Surgery, 7, 69-76. https://doi.org/10.4055/cios.2015.7.1.69

[14] Leylabadlo, H.E., Zeinalzadeh, E., Akbari, N.A.R. and Kafil, H.S. (2016) Malassezia Species Infection of the Synovium after Total Knee Arthroplasty Surgery. GMS Hygiene and Infection Control, 11.

[15] Everhart, J.S., Sojka, J.H., Mayerson, J.L., Glassman, A.H. and Scharschmidt, T.J. (2018) Perioperative Allogeneic Red Blood-Cell Transfusion Associated with Surgical Site Infection after Total Hip and Knee Arthroplasty. JBJS, 100, 288-294.

https://doi.org/10.2106/JBJS.17.00237 